\title{
Determination of some carcinogenic PAHs with toxic equivalency factor along roadside soil within a fast developing northern city of India
}

\author{
Vaneet Kumar ${ }^{1, *}$ N C Kothiyal ${ }^{1}$, Saruchi $^{1}$, R Mehra ${ }^{2}$, \\ A PARKASH ${ }^{3}, \mathrm{R}$ R Sinha ${ }^{4}, \mathrm{~S}$ K TAYAGI ${ }^{5}$ and R GABA ${ }^{6}$ \\ ${ }^{1}$ Department of Chemistry, ${ }^{2}$ Department of Physics, ${ }^{3}$ Department of Humanities, \\ ${ }^{4}$ Department of Mathematics \\ ${ }^{1-4}$ Environmental Chemistry Laboratory, $\operatorname{Dr} B$ R Ambedkar National Institute of Technology, \\ Jalandhar, Punjab 144 011, India. \\ ${ }^{5}$ Centre Pollution Control Board, New Delhi. \\ ${ }^{6}$ DAV University, Jalandhar, Punjab, India. \\ ${ }^{*}$ CT Group of Institutions, Jalandhar, Punjab. Also Corresponding author. \\ e-mail: vaneet2106@gmail.com
}

The objective of the present study was to ascertain contamination levels, distribution behaviour and PAHs exposure during summer, winter and autumn during 2011-2012 in one of the developing cities of northern India. Average PAHs concentration was found to be 18.17, 4.04 and $16.38 \mu \mathrm{g} \mathrm{g}^{-1}$, whereas, concentration of 16 individual PAHs was found to vary between 0.02 and 200.23, 0.008 and 28.4 $\mu \mathrm{g} \mathrm{g} \mathrm{g}^{-1}$, and 0.01 and $252.55 \mu \mathrm{g} \mathrm{g}^{-1}$ during summer, winter and autumn seasons, respectively. The average concentration of low and high carcinogenic PAHs during summer, winter and autumn was found to be 5.1 and $31.29,2.1$ and $6.4,4.74$ and $35.08 \mu \mathrm{g} \mathrm{g}^{-1}$ at most intercepts. The average ratio of low to high carcinogenic PAHs was found to be 1:6, 1:3, 1:7.6 during summer, winter and autumn, respectively. Five ringed PAHs were found in higher concentration in all seasons. Dib(ah)A and $\mathrm{B}(\mathrm{a}) \mathrm{P}$ were the two individual PAHs found in highest concentration during summer, winter and autumn seasons. Two tailed T-test was applied for authenticity of the results. Toxic equivalency factor of B(a)P and Dib(ah)A was maximum as compared to other PAHs. The study could be of great significance for the planners while considering environmental remedial measures.

\section{Introduction}

The impact of automobile exhaust emissions in environment, predominantly on soil, air and water is increasing day by day (Hunter et al. 1979; Kumata et al. 2000). A few toxic contaminants found in roadside soil include Polycyclic Aromatic Hydrocarbons (PAHs) and heavy metals. A large number of PAHs exist in the environment, some of which are known as potential carcinogens and mutagens (Neilson 1998). The persistence of PAHs in environment is lower than that of heavy metals. Degradation rate of PAHs adsorbed into sediments or soil is very slow and depends on several factors. Slow degradation of these PAHs pose a potential risk to human being coming in contact with contaminated roadside soil (Cornelissen et al. 1998). Some studies have reported the major origin of PAHs in roadside soil as exhaust gases from automobile (Takada et al. 1990). Other

Keywords. Polycyclic aromatic hydrocarbons; contamination; pollution; meteorological; environment. 
sources of PAHs in environment include automobile exhaust, lubricating oils, atmospheric depositions, power plants, domestic heating systems, petrol/ diesel engines and various industrial activities (Williams 1990; Mastral et al. 1996; Lee et al. 1998). PAH concentrations in soil were assumed to be influenced by traffic and population density, road condition, traffic behaviour, meteorological condition and rate of deposition (Edwards 1989; Jones et al. 1989). Concentration of PAHs in roadside soil was found to vary according to distance from the source of origin (Li et al. 2006). Once such PAHs percolate into the soil, they got accumulated in horizons rich in organic matter, where they are likely to be retained for many years due to their persistence, hydrophobicity and slow degradation rate (Krauss et al. 2000).

Literature survey shows a very limited soil PAHs contamination in any developing city of India, where two, three and four wheelers (car, truck and buses) with varying oldness ranging from 1 to 20 years ply on the same roads (Kumar and Kothiyal 2011a, b, 2012). Lack of infrastructure, maintenance, poor planning, slow pace of infrastructure development and socio-economic condition has aggravated the problem further. Smaller vehicles (two, three and four wheelers) which run mainly on petrol and diesel have contributed a lot to PAHs in city environment (air and soil). PAHs have drawn considerable attention of scientific community due to their carcinogenic and mutagenic behaviour (Yang et al. 1991). It is important to understand type and distribution behaviour of PAHs in soil and how their concentration in soil varies significantly with seasons and correlate it with the corresponding levels in air (Nam et al. 2003). Developing cities like Jalandhar are showing even equal or higher concentration of some PAHs (Kumar and Kothiyal 2011b) and their concentrations have been found in higher side during autumn (Kumar and Kothiyal 2011a, 2012). In India, especially in metropolitan cities, extensive literature shows the presence of PAHs mostly in ambient air, roadside dust and soil. The objective of the present study was to determine the concentration level, ratio of high and low carcinogenic PAHs, distribution behaviour (16 carcinogenic PAHs identified EPA), toxic equivalency factor and statistical analysis of results during summer, winter and autumn in the roadside soil. Samples of soil were taken at a distance of 1 , 2 and $3 \mathrm{~m}$ from the roadside soil at places of high/average traffic and population density within city in the state of Punjab, India. The database generated from this study will be of immense importance in characterizing roadside soil with respect to PAHs in developing city environment of India.

\section{Materials and methods}

The major road intercepts chosen as sampling sites were Maqsuda (J1), DAV (J2), Patel (J3), Workshop (J4), Jyoti (J5), Mission (J6), BMC (J7), Bus Stand (J8), Nakodar (J9) and Football (J10) chowks (intercepts).

\section{Calibration procedure}

We have selected more than one internal standards that are similar in analytical behaviour to the compounds of interest. The measurement of the internal standard is not affected by method or matrix interference. The following deuterated $\mathrm{PAH}$ compounds are used to pre-spike the sample extracts: Napthalene d8; Acenapthene d10; Fluorene d10; Phenanthrene d10; Benzo(a)anthracene d12; Chrysene d12 and Perylene d12.

The base peak ion is used as the primary ion for quantification of the standard compounds. If interferences are noted, the next two most intense ions are used as the secondary ions. The internal standard compound is added to all calibration standard solutions and all sample extracts to be analyzed by gas chromatograph. Retention time, column performance and a mass spectrometer timing standard compounds were included in the internal standard solution used.

Four concentration levels calibration standard solutions of PAHs were prepared at a minimum of by adding appropriate volumes of one or more stock standard solutions to a volumetric flask. The stock standard solutions were prepared from certified solutions of $2000 \mu \mathrm{g} / \mathrm{mL}$ of each analyte of interest (Merk, Germany). The stock standard solutions were prepared at concentrations of $100 \mu \mathrm{g} / \mathrm{mL}$ in toluene. A calibration table is constructed from instrument responses for target compound challenge concentrations of 25, 50, 100 and $250 \mathrm{ng} / \mathrm{nL}$. To each calibration standard solution, $100 \mathrm{ng} / \mu \mathrm{L}$ of deuterated internal standard was added.

Calibration standard solutions were at a concentration near but above the maximum detection limit and the other concentrations should correspond to the expected range of concentrations found in real samples or define the working range of the GC system.

$\mathrm{RF}$ value on the working range was a constant $(<10 \%$ RSD), the RF assumed to be invariant and the average RF was used for calculations. Alternatively, the results were used to plot a calibration curve of response ratios, As/Ais vs. RF.

The working calibration curve or RF was verified on each working day by the measurement of one or more calibration standard solutions. If 
the response for any analyte varies from the predicted response by more than $\pm 10 \%$, the test was repeated using a fresh calibration standard solution.

\subsection{Sampling sites}

Punjab is one of the prosperous and most developing states of India. Jalandhar, one of the major expanding cities situated at the centre of Punjab between Beas and Sutlej rivers. The city, which has major road and rail links, is a market for agricultural, textile, leather goods, wood products, hand tools and sports materials. Jalandhar is located at $710^{\circ} 31^{\prime} \mathrm{E}$ and $300^{\circ} 33^{\prime} \mathrm{N}$ at a distance of $146 \mathrm{~km}$ from the state capital Chandigarh on Delhi-Amritsar National Highway (NH-1). According to 2011 Census (provisional), the area of Jalandhar district is $3401 \mathrm{~km}^{2}$ and total population of the district was 2553,508 persons. The city has shown tremendous growth in terms of population, infrastructure and traffic density during last few years. The climate, on the whole, is dry except during the brief south-west monsoon season (July to September). The average annual rainfall in the district is $703.0 \mathrm{~mm}$. Ten sampling locations (both public and commercial places) were chosen on the basis of high traffic density, urban populations and geographical dispersion. Major road intercepts chosen as sampling sites were Maqsuda (J1), DAV (J2), Patel (J3), Workshop (J4), Jyoti (J5), Mission (J6), BMC (J7), Bus Stand (J8), Nakodar (J9) and Football (J10) chowks (intercepts).

ased on population and traffic density, above 10 locations were divided into places of high population and traffic density, i.e., site 1 (where traffic was high but slow during 9 am- 9 pm) and places of average traffic and population density, i.e., site 2 (places with normal traffic speed and average population density during 9 am- $9 \mathrm{pm}$ ). Figure 1 shows the road map of sampling sites and their location codes.

\subsection{Sampling period and meteorological condition}

The samples were taken for a span of one year during autumn, winter and summer seasons during 2011-2012. A total of 90 samples were collected from 10 different locations (J1-J10). During autumn, maximum/minimum temperature during the sampling period was $35^{\circ} \mathrm{C} / 30^{\circ} \mathrm{C}$ and humidity was between 20 and $80 \%$; during winter, temperature was between $20^{\circ} \mathrm{C}$ and $10^{\circ} \mathrm{C}$, and humidity was $75-30 \%$ whereas, during summer temperature was between $47^{\circ} \mathrm{C}$ and $5^{\circ} \mathrm{C}$ and humidity was $85-$ $15 \%$ and the entire region receive dense fog at night and day at winter.

\subsection{Sampling technique}

From each sampling location, three soil samples were collected from 1,2 , and $3 \mathrm{~m}$ distance from different directions of the road (left and right sides). Samples were collected by scooping $6 \mathrm{~cm}$ below the surface layer. The samples in bulk collected were stored in polyethylene bags and were brought to the laboratory. Stones, leaves, debris and other extraneous materials were sieved out before analysis. All the samples were dried in a hot air oven maintained at $40^{\circ} \mathrm{C}$ for $24 \mathrm{hrs}$ for the removal of free moisture. The samples were preserved in desiccators and stored in dark before extraction.

\subsection{Chemicals}

HPLC grade reagents, solvents and standards used in this study were procured from Merck Chemicals Pvt. Ltd., Mumbai, India. PAH standards used in soil study were procured from Dr Ehrenstorfer GmbH Chemicals, Merck, Germany.

\subsection{Glasswares}

A grade borosil made glasswares were used in the study. Glasswares were dipped in dilute Nitric acid and washed with plain and double distilled water every time before use.

\subsection{Equipments}

PAHs present in the samples were analyzed on Nucon made microprocessor based Gas Chromatograph (Model No. 5765), using RH-5 capillary column (60 m length, 0.53 ID X 3.0 mm using FID detector). Rotavapor and soxhlet extraction apparatus were used for extraction of PAHs from the soil.

\subsection{Extraction of PAHs}

About 20 gm of pre-dried soil samples were heated at $400^{\circ} \mathrm{C}$ to remove any trace of moisture before extraction. Dried soil samples were transferred in soxhlet apparatus and extracted using acetone and dichloromethane (1:1) as solvents at the rate of 3 cycles per hour for 8 -h. Soxhlet extraction [DCM-acetone (1:1)] over an 8-h period recovered $95 \%$ of the PAHs (Guerin 1998). The extract was allowed to cool and filtered through a Whatman filter paper. The filtrate was concentrated to 1 $\mathrm{ml}$ using rotary evaporation at $60^{\circ} \mathrm{C}$ under gentle vacuum. The samples prepared were preserved in amber coloured sample tubes stored in refrigerator below $4^{\circ} \mathrm{C}$ before analysis. Samples were 


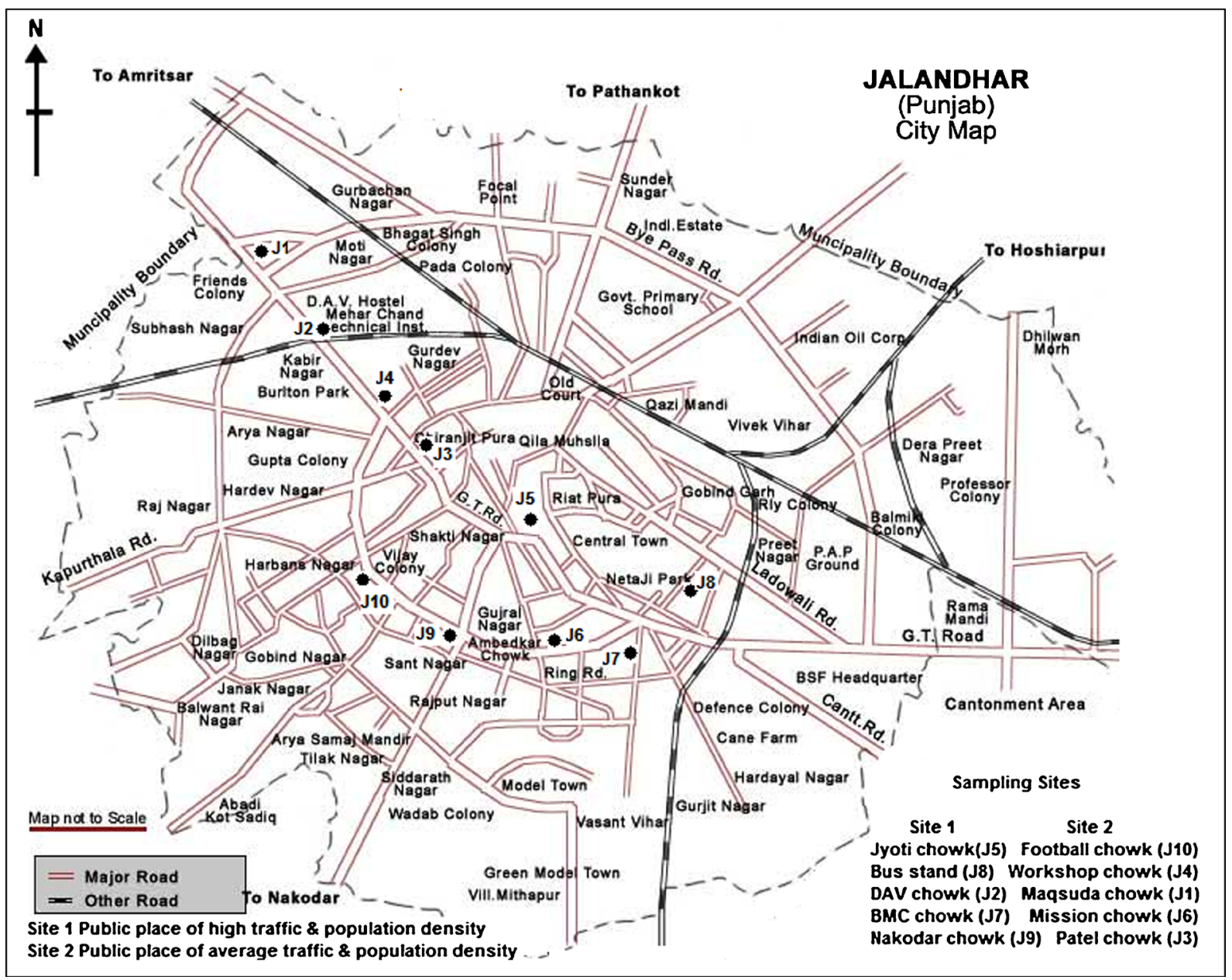

Figure 1. Map of Jalandhar city showing sampling locations.

later analyzed for types and concentration of PAHs by GC. The procedure described above has been checked for recovery efficiencies using spiked PAHs standard. Recovery range was between 30 and $70 \%$ with the lower value corresponding to the lower molecular weight PAHs compound. Presented data are corrected accordingly with the mean of triplicate analyses. Replicated analyses give an error between $\pm 10 \%$ and $\pm 20 \%$ for PAHs in soils (Kumar and Kothiyal 2011a, b, 2012).

\section{Results and discussion}

The results of average concentration of PAHs determined in 120 soil samples during one year at different distances from roadside soil have been shown in table 1 . The 10 sampling locations were divided into high/average population and traffic density areas and categorized as site 1 /site 2 (table 1). In the present study, 16 PAHs (EPA identified) were determined namely Nap, Napthalene; Ace Nap, Acenapthene; Ace Naph, Acenapthylene; Flu Fluorene; Phen, Phenanthrene; Anth, Anthracene;
Flan, Fluoranthene; Pyr, Pyrene; B(a)A, Benzo(a) Anthracene; Chry, Chrysene; B(b)F, Benzo(b) Fluoranthene; B(k)F, Benzo(k) Fluoranthene; B(a)P, Benzo(a)Pyrene; IP, Indeno(123cd) Pyrene; Dib(ah)A, Di Benzo(ah) Anthracene and B(ghi)P, Benzo (ghi) Pyrelene.

\subsection{Behaviour of PAHs at places of high population and traffic density intercepts}

Type and concentration of PAHs at various intercepts were found to differ from place to place. Average concentration of 16 PAHs at a distance of 1-3 $\mathrm{m}$ were determined during different seasons and the results obtained are shown in table 1 . Figure 2(a) shows variation of concentration (average) with distance during three seasons. The results shown in figure 2(a) indicated that the average concentration of PAHs decreases with distance from roadside soil in most cases from 1 to $3 \mathrm{~m}$ distance during three seasons. The observed behaviour was perhaps due to close proximity of intercepts from roadside in the form of buildings, plants and shops in the area of high population and traffic density. It has been 
Table 1. Seasonal average of 16 PAHs found in roadside soil at 1, 2 and $3 m$ distance from roadside at places of average and high traffic and population density.

\begin{tabular}{|c|c|c|c|c|c|c|c|c|c|c|}
\hline \multirow[b]{3}{*}{ Sl. no. } & \multirow[b]{3}{*}{ Sampling locations } & \multicolumn{9}{|c|}{$\begin{array}{l}\text { Average concentration of } 16 \text { PAHs in } \mu \mathrm{g} \mathrm{g}^{-1} \text { at } \\
\text { different distances from roadside (in meters) }\end{array}$} \\
\hline & & \multicolumn{3}{|c|}{ Summer } & \multicolumn{3}{|c|}{ Winter } & \multicolumn{3}{|c|}{ Autumn } \\
\hline & & $1 \mathrm{~m}$ & $2 \mathrm{~m}$ & $3 \mathrm{~m}$ & $1 \mathrm{~m}$ & $2 \mathrm{~m}$ & $3 \mathrm{~m}$ & $1 \mathrm{~m}$ & $2 \mathrm{~m}$ & $3 \mathrm{~m}$ \\
\hline \multicolumn{11}{|c|}{ Site 1 (High traffic and population density intercepts) } \\
\hline 1 & Jyoti Chowk (J5) & 24.04 & 16.42 & 17.70 & 7.39 & 3.25 & 3.91 & 39.96 & 7.89 & 13.81 \\
\hline 2 & Bus Stand (J8) & 11.95 & 16.21 & 7.90 & 10.80 & 4.14 & 4.10 & 25.26 & 16.90 & 13.27 \\
\hline 3 & Nakodar Chowk (J9) & 7.58 & 1.69 & 2.09 & 12.26 & 3.28 & 3.66 & 41.50 & 21.08 & 19.93 \\
\hline 4 & $\mathrm{DAV}(\mathrm{J} 2)$ & 27.25 & 13.88 & 6.59 & 5.60 & 4.18 & 1.22 & 46.46 & 11.74 & 11 \\
\hline \multirow[t]{3}{*}{5} & BMC Chowk (J7) & 45.09 & 23.40 & 49.70 & 4.66 & 1.72 & 4.74 & 15.80 & 10.34 & 0.77 \\
\hline & Average & 23.18 & 14.32 & 16.79 & 8.14 & 3.31 & 3.52 & 33.79 & 13.59 & 11.75 \\
\hline & $\pm \mathrm{SD}$ & 14.72 & 7.90 & 19.25 & 3.28 & 0.99 & 1.34 & 12.79 & 5.32 & 6.97 \\
\hline \multicolumn{11}{|c|}{ Site 2 (Average traffic and population density intercepts) } \\
\hline 6 & Football Chowk (J10) & 8.20 & 24.56 & 0.15 & 1.60 & 3.48 & 1.11 & 3.03 & 11.06 & 2.32 \\
\hline 7 & Workshop Chowk (J4) & 21.79 & 5.75 & 5.56 & 4.83 & 6.15 & 1.65 & 46.54 & 11.65 & 3.29 \\
\hline 8 & Patel Chowk (J3) & 0.35 & 21.30 & 28.38 & 2.30 & 6.76 & 3.62 & 6.70 & 4.08 & 11.18 \\
\hline 9 & Maqsuda Chowk (J1) & 19.92 & 13.76 & 16.03 & 0.98 & 1.46 & 3.75 & 13.05 & 11.68 & 21.87 \\
\hline \multirow[t]{3}{*}{10} & Mission Chowk (J6) & 40.13 & 4.91 & 13.72 & 4.40 & 3.44 & 1.09 & 45.25 & 26.30 & 10.99 \\
\hline & Average & 18.07 & 14.05 & 12.76 & 2.82 & 4.25 & 2.24 & 22.91 & 12.95 & 9.93 \\
\hline & $\pm \mathrm{SD}$ & 15.12 & 8.88 & 10.79 & 1.70 & 2.17 & 1.33 & 21.28 & 8.12 & 7.86 \\
\hline
\end{tabular}

interpreted from table 1 that the average highest concentration of 16 PAHs among five locations was $49.70 \mu \mathrm{g} \mathrm{g}^{-1}$ at a distance of $3 \mathrm{~m}$ from roadside at the location J7. The observed value was perhaps highest in roadside soil among metro or fast developing cities within India or other cities of the world. Pyr and IP were two PAHs (among 16 PAHs) found in higher concentration, i.e., 28.4 and $250.64 \mu \mathrm{g}$ $\mathrm{g}^{-1}$ (at 1 and $2 \mathrm{~m}$ distances) at $\mathrm{J} 2$ respectively, during winter and autumn, whereas, $\mathrm{B}(\mathrm{a}) \mathrm{P}$ was individual $\mathrm{PAH}$ found in highest concentration, i.e., $200.23 \mu \mathrm{g} \mathrm{g}^{-1}$ (at $1 \mathrm{~m}$ distance) at J7 during summer. Average concentration of individual PAHs (1 to $3 \mathrm{~m}$ of 5 locations) has been shown in figure 3(a). Figure 3(a) indicates that $\mathrm{B}(\mathrm{a}) \mathrm{P}$ was an individual $\mathrm{PAH}$ found in highest concentration in most intercepts during summer and autumn, whereas, Dib(ah)A was in highest concentration during winter. The results indicated that concentration of the individual PAH (average of 16 PAHs) varies from place to place seasonally. Location J2 was an intercept surrounding by 6-7 educational institutes, where thousands of students were exposed to high the \% of PAHs. The result indicated that there was a distinct variation in PAHs concentration with seasons and meteorological conditions round the year. In general, concentration of all PAHs during winter was low as compared to summer and autumn. The winter season in the city experiences high humidity and dense fog during day and night and temperature drops to zero and subzero. During winter due to high humidity and dense fog in the day time, less photochemical degradation of these PAHs is responsible for low concentration of PAHs in the environment.

\subsection{Behaviour of PAHs at places of average population and traffic density intercepts}

Average concentration of 16 PAHs at $1-3 \mathrm{~m}$ was determined during three seasons and the results obtained are shown in table 1. Figure 2(b) shows variation in concentration of PAHs (average) with distance and their seasonal variation. The results shown in figure 2(b) indicated that the average concentration of 16 PAHs does not show any set pattern during three seasons. Larger open area along roadside at these intercepts was responsible for different dispersion, suspension and distribution behaviour of PAHs. It has been interpreted from table 1 that the average highest concentration of $16 \mathrm{PAHs}$ in five locations was $46.54 \mu \mathrm{g} \mathrm{g}^{-1}$ at a distance of $1 \mathrm{~m}$ from roadside soil at location $\mathrm{J} 4$ during autumn. The observed value was perhaps the highest value in roadside soil, among any metro or fast developing city within India. Dib(ah)A was an individual PAH (among $16 \mathrm{PAHs}$ ) found in highest concentration, i.e., 26.4 and $252.55 \mu \mathrm{g} \mathrm{g}$ (at 1 and $3 \mathrm{~m}$ distances) at $\mathrm{J} 4$ and $\mathrm{J} 1$ during winter and autumn, whereas, Dib(ah)A was an individual $\mathrm{PAH}$ found in highest concentration, i.e., $219.79 \mu \mathrm{g} \mathrm{g}^{-1}$ (at $2 \mathrm{~m}$ distance) at J10 during summer. Average concentration of individual PAHs (average within 1 to $3 \mathrm{~m}$ distance) are shown in figure 3(b). Figure 3(b) indicated that B(a)P was an individual $\mathrm{PAH}$ found in highest concentration 
High traffic and population density intercepts
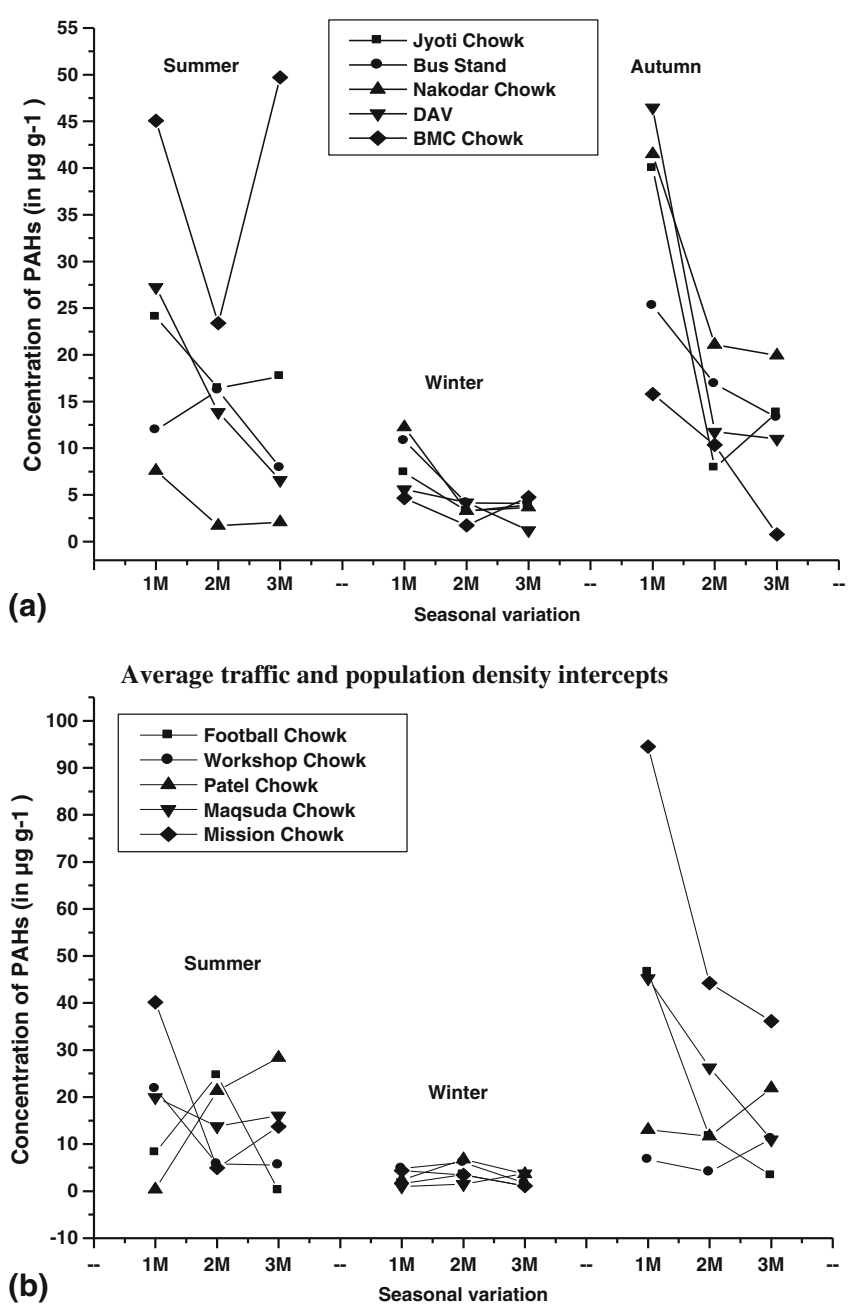

Figure 2. Seasonal variation of average PAHs concentration (16 PAHs) in roadside soil as a function of distance in major traffic intercepts (a) at high traffic and population density intercepts and (b) at average traffic and population density intercepts.

in almost all intercepts during summer and autumn, whereas, Dib(ah)A was found in highest concentration during winter. PAHs contamination some time give more serious risk when their concentration exceed recommended maximum limit than those related to outdoor PAHs exposure (Banerjee 2008).

\subsection{Ringwise distribution pattern of high and low carcinogenic PAHs at high and average traffic and population density intercepts}

Ringwise distribution pattern, concentration and seasonal variation of $2,3,4,5$ and 6 ringed PAHs (average percentage concentration within $3 \mathrm{~m}$ ) are shown in figure 4 . The result indicated that five ringed $\mathrm{PAHs}$, i.e., $\mathrm{B}(\mathrm{a}) \mathrm{P}, \mathrm{B}(\mathrm{k}) \mathrm{F}, \mathrm{B}(\mathrm{b}) \mathrm{F}$ and $\operatorname{Dib}(\mathrm{ah}) \mathrm{A}$ were present in highest concentration (around 70\%), whereas, two ringed PAHs were in lowest concentration (around 0.50\%). In general, the ringwise order of PAHs concentration (\% age) was $5>4>6>3>2$ during summer and winter, whereas, $5>6>4>3>2$ during autumn seasons.

USEPA has classified seven PAHs as probable human carcinogens, i.e., $\mathrm{B}(\mathrm{a}) \mathrm{P}, \mathrm{B}(\mathrm{k}) \mathrm{F}, \mathrm{B}(\mathrm{b}) \mathrm{F}$, Dib(ah)A, B(a)A, IP, B(ghi)P) (Lunch 2005). Out of seven EPA identified PAHs, four are five ringed, two are six ringed, and one of them is four ringed PAH. All the seven PAHs were found in the current area of the study. The results indicated that percentage of high carcinogenic PAHs in soil within developing city environment of present study was quite high. Seasonal variation of high and low carcinogenic PAHs (average concentration in total) observed in the study at average and high traffic population density intercepts are shown in figure 5(a and b). Result indicated that total percentage of probable human high carcinogenic PAHs at average and high traffic population density intercepts were as high as $85 \%$, whereas, low carcinogenic PAHs were only $15 \%$. The ratio of high and low carcinogenic PAHs was found to be 5.1 and $31.29 \mu \mathrm{g} \mathrm{g}^{-1}$ (1:6) during summer, 2.1 and $6.4 \mu \mathrm{g}$ $\mathrm{g}^{-1}$ (1:3) during winter, and 4.74 and $35.8 \mu \mathrm{g} \mathrm{g} \mathrm{g}^{-1}$ (1:7.55) during autumn. The high ratio of high and low carcinogenic PAHs at most intercepts in any fast developing city is the sign of potential risk to the residents of the city.

\section{Seasonal variation}

Sampling periods of the present study was broadly divided into three seasons, i.e., winter (NovemberFebruary), summer (March-June) and autumn (July-October). Figures 2-5 summarize the average concentrations, ringwise distribution pattern, seasonal variation and ratio of low and high carcinogenic PAHs in soil at two sites. The concentration of PAHs (city average) during summer and autumn was higher as compared to winter season, i.e., $18.17,16.38$ and $4.04 \mu \mathrm{g} \mathrm{g}^{-1}$, respectively. The difference in PAHs concentration in soil during different seasons was perhaps due to the characteristics of individual sites, vehicular and population density and meteorological condition during the period. Figure 2(a) showed that, in general, average concentration of PAHs during three seasons was maximum near the road and minimum away from the road at most intercepts. From the studied area, the dense fog was found during entire winter season with temperature decline below zero degree. Differences in dispersion and distribution of soot and smoke during winter due to fog has changed the dispersion and setting behaviour which leads to decline in PAHs concentration during the seasons. 


\section{High traffic and population density intercepts}

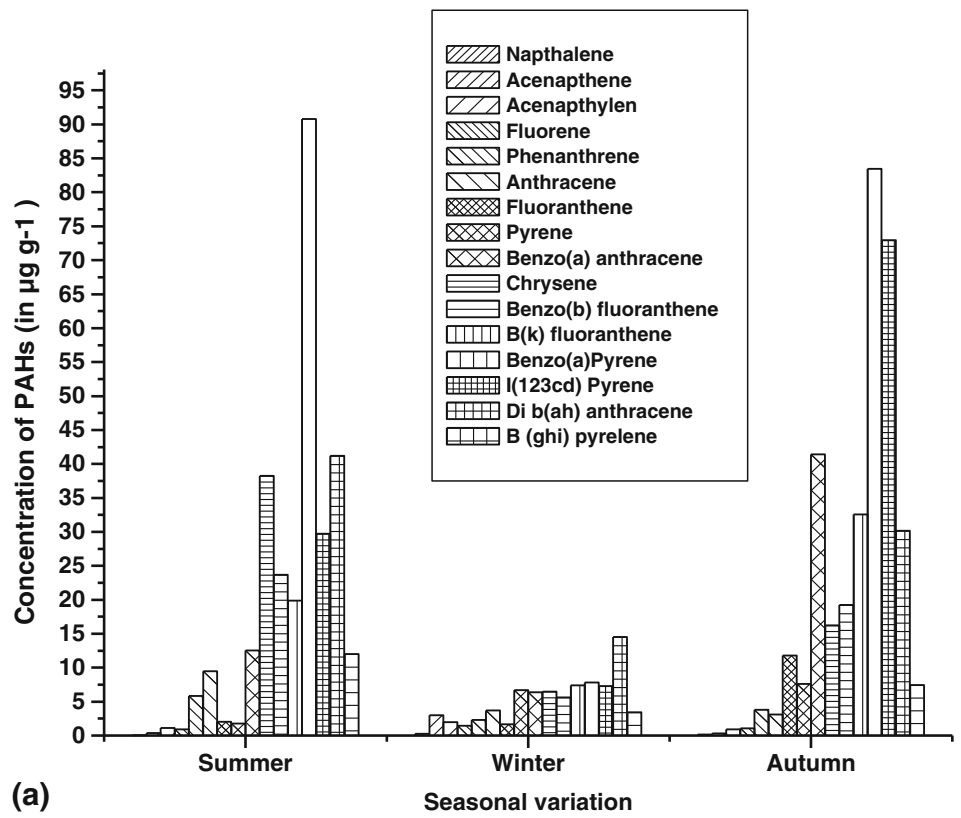

Average traffic and population density intercepts

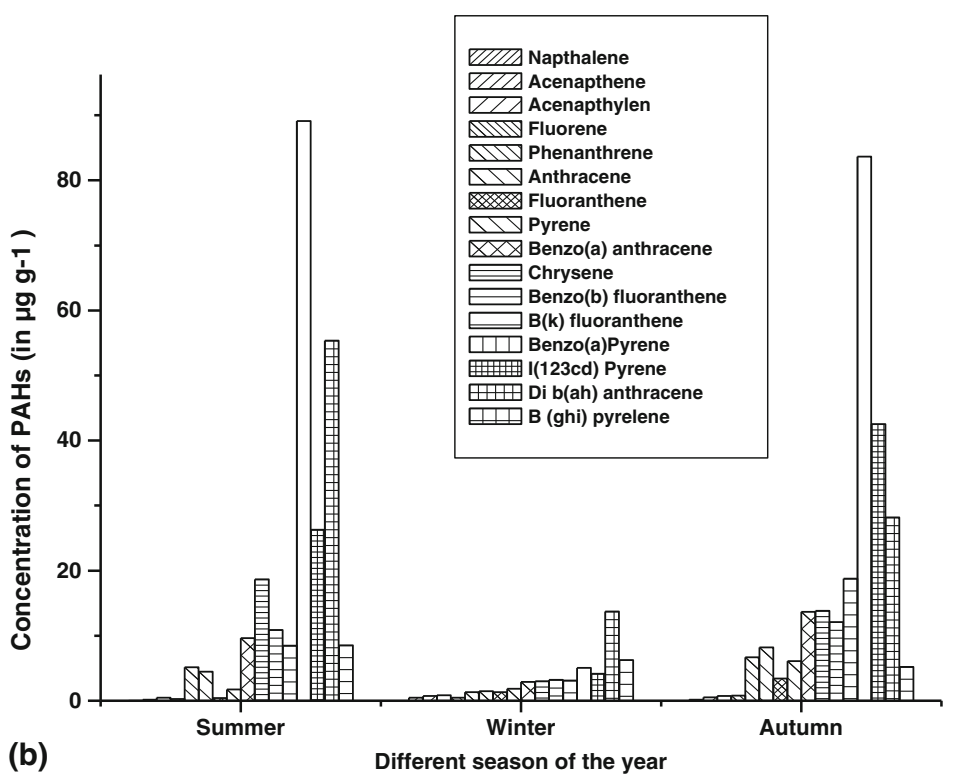

Figure 3. Seasonal variation of average individual PAH in roadside soil in major traffic intercepts (a) at high traffic and population density intercepts and (b) at average traffic and population density intercepts.

Figure 2( $\mathrm{a}$ and $\mathrm{b})$ indicated that in general average concentration of PAHs was maximum during autumn and summer as compared to winter season. The result indicated that seasonal variation and concentration of PAHs at various intercepts was directly related. Figure 3(a and b) indicated that average concentration of individual PAHs was higher during autumn and summer as compared to winter season. Average concentration of individual $\mathrm{PAH}$ was highest at high traffic intercepts than average traffic density intercepts. Result also indicated that higher molecular weight PAHs (4, 5 and 6 rings) were in higher concentration as compared to lower molecular weight PAHs (2 and 3 rings). Average concentration of $\mathrm{B}(\mathrm{a}) \mathrm{P}$ was maximum during summer and autumn, whereas, Dib(ah)A was highest during winter at high/average traffic density intercept. Average individual PAHs concentration was highest during autumn and summer as compared to winter. 


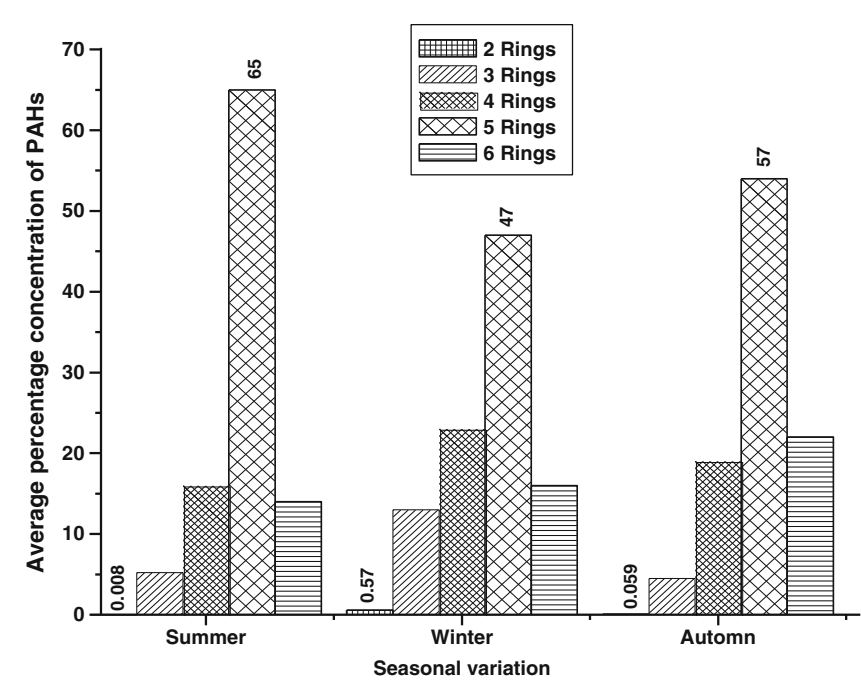

Figure 4. Ringwise distribution pattern of average 16 PAHs identified at average and high traffic population density intercepts.

Temperature of soil was an important factor in determining the mobility of soil PAHs. Summer and autumn seasons of sampling region receives high temperature ranging from $35^{\circ}$ to $48^{\circ} \mathrm{C}$. During autumn and summer, city environment was dry, cool and experienced high concentration of particulate matter which adsorbs many volatile and nonvolatile PAHs and settles in nearby area along roadside, results higher concentration during autumn and summer. Figure 4 indicated that average PAH percentage concentration of five ringed PAH was higher during summer and autumn as compared to winter. Results indicated that five ringed PAHs were in the highest concentration in all three seasons which is a dangerous sign for the human beings living near the roadside. Figure 5 (a and $b$ ) indicated that concentration of high carcinogenic PAHs was higher at high traffic density intercepts as compared to average traffic density intercepts. Average concentration of high/low carcinogenic PAHs during autumn and winter at high and average traffic density was 41.02, 29.15 and $4.99,4.49$ and $7.48,5.47$ and $3.06,1.27 \mu \mathrm{g}$ $\mathrm{g}^{-1}$, respectively, whereas, average concentration of high and low carcinogenic PAHs during summer at high and average traffic density was $32.83,29.75$ and $6.64,3.47 \mu \mathrm{g} \mathrm{g}^{-1}$, respectively. The current results indicate that highest concentration of high carcinogenic species and its exposure to human being may be harmful to the people travelling through these regions.

\section{Statistical analysis of results}

In order to find exposure of the PAHs to human from roadside soil at high/average population and
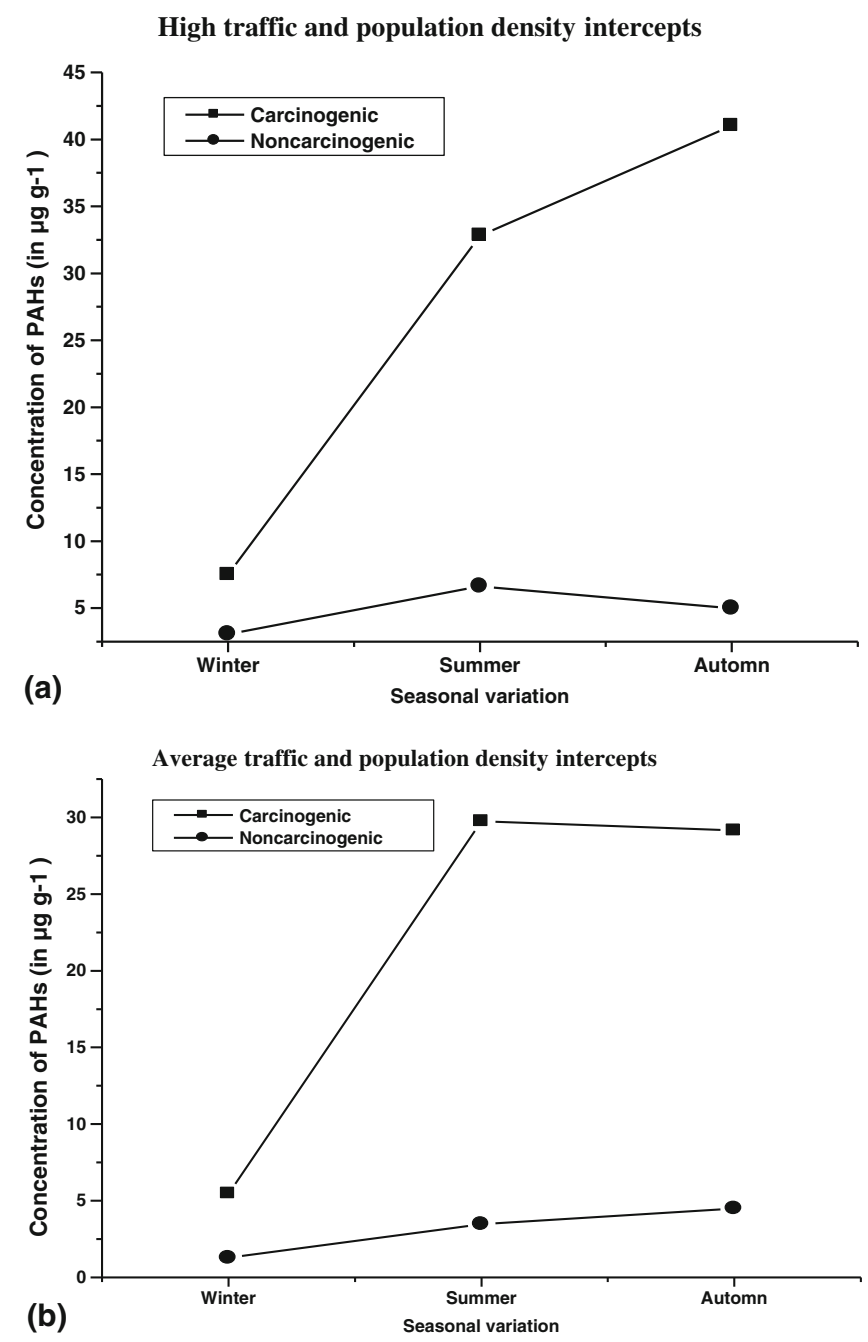

Figure 5. Seasonal distribution behaviour of high carcinogenic (seven) and low carcinogenic (nine) PAHs (a) at high traffic and population density intercepts and (b) at average population density intercepts.

traffic density intercepts of the city, the ratio of high and low carcinogenic PAHs was determined. Ratio of high and low carcinogenic PAHs were highest in autumn than in winter and summer. Although there was no toxicity limit fixed for PAHs along roadside soil in India, the high and low carcinogenic PAHs results were found to be significant due to high ratio of these PAH in roadside soil. Due to no PAHs limiting values in soil in India, the present data was compared with Mexican standards $\left(0-6 \mu \mathrm{g} \mathrm{g}^{-1}\right)$, Polish standards $(0.02-10 \mu \mathrm{g}$ $\mathrm{g}^{-1}$ ) (Skrbic et al. 2005) and worldwide data given in table 2. Comparing Jalandhar city average in autumn (16.38 $\left.\mu \mathrm{g} \mathrm{g}^{-1}\right)$, summer $\left(18.17 \mu \mathrm{g} \mathrm{g} \mathrm{g}^{-1}\right.$ ) and winter $\left(4.04 \mu \mathrm{g} \mathrm{g}^{-1}\right)$ of 16 PAHs with available literature data, it was found to be quite high as compared to many other cities of the world such as Kota Bharu Malaysia, $1.45 \mu \mathrm{g} \mathrm{g}^{-1}$ (Fadzil et al. 2008), Australia, $3.30 \mu \mathrm{g} \mathrm{g}^{-1}$ (Yang et al. 1991), 
Table 2. Soil PAH concentration (roadside urban) compiled from literature data.

\begin{tabular}{llll}
\hline Sl. no. & \multicolumn{1}{c}{ Study area } & PAH concentration & Reference \\
\hline 1 & Australia & 3.30 & Yang et al. (1991) \\
2 & USA & 58.68 & Rogge et al. $(1993)$ \\
3 & Kota Bharu, Malaysia & 1.45 & Fadzil et al. (2008) \\
4 & Mexican standards \& polish standards & $0-6,0.02-10$ & Skrbic et al. (2005) \\
5 & Agra, India & 12.9 & Masih Amit and \\
& & & Ajay Taneja (2006) \\
6 & Delhi airport soil data, India & 4.43 & Ray et al. (2008) \\
7 & Jalandhar (summer, winter and autumn), India & $18.17,4.04$ and 16.38 & Present study \\
\hline
\end{tabular}

near Delhi airport soil data in winter, $4.43 \mu \mathrm{g} \mathrm{g} \mathrm{g}^{-1}$ (Ray et al. 2008), Agra, India, $12.9 \mu \mathrm{g} \mathrm{g}^{-1}$ (Masih Amit and Ajay Taneja 2006), but lower than few other cities of the world such as USA, $58.68 \mu \mathrm{g} \mathrm{g} \mathrm{g}^{-1}$ (Rogge et al. 1993). In order to compare the city average concentration of 16 PAHs of developing city like Jalandhar with other cities of India, two tailed t-test was applied to the data. The results of the test applied to Jalandhar city average in autumn (16.38 $\mu \mathrm{g} \mathrm{g}^{-1}$ current study), a developing city to that of New Delhi airport soil data (4.43 $\mu \mathrm{g} \mathrm{g}^{-1}$ ), a metro city (Ray et al. 2008), indicated that the data of two places differ significantly at $5 \%$ level of significance. This shows that PAH contamination level and distribution pattern of two places were quite different.

The results of the test applied to Jalandhar city average during winter (4.04 $\mu \mathrm{g} \mathrm{g}^{-1}$ current study), a developing city to that of New Delhi airport soil data $\left(4.43 \mu \mathrm{g} \mathrm{g}^{-1}\right.$ ), a metro city (Ray et al. 2008), indicated that it does not significantly differ at $5 \%$ level of significance. This showed equal level of PAHs contamination at two places. On the other hand, on applying the test for Malaysia roadside (Fadzil et al. 2008) soil data $\left(1.45 \mu \mathrm{g} \mathrm{g}^{-1}\right)$, the data of two places differ significantly at $5 \%$ level of significance. This shows that PAH contamination level and distribution pattern of two places were quite different. The results of the test applied to Jalandhar city average during summer (18.17 $\mu \mathrm{g} \mathrm{g}^{-1}$ current study), a developing city to that of roadside data of Agra city $\left(12.98 \mu \mathrm{g} \mathrm{g} \mathrm{g}^{-1}\right)$, the data of two places differ significantly at $5 \%$ level of significance. This shows that PAH contamination level and distribution pattern of two places were quite different.

Results obtained by two tailed t-test are found to be statistically significant for authenticity of our data and results. Our data indicated that people living in these areas were at potential risk of exposure to the carcinogenic effect of various types of PAHs, in agreement with other studies, which demonstrated a potential risk for exposure to high levels of PAHs for road users and those living in urban environment of developing city.

\section{Toxic equivalency factor}

TEF evaluation is the most popular method used to identify the toxicity of PAHs. Toxicity equivalency concentrations (TEQs) are calculated as the product of summing up the values obtained by TEF values and concentrations of PAHs, as follows:

$$
\mathrm{TEQ}=\sum(\mathrm{Ci} \times \mathrm{TEFi})
$$

where TEQ is the toxic equivalent concentration and $\mathrm{Ci}$ is the concentration of PAHi.

Petry et al. (1996) used TEFs in assessing occupational and environmental health risks associated with exposure to airborne mixtures of PAHs. They used information of the ratio between soil concentrations of $\mathrm{B}(\mathrm{a}) \mathrm{P}$ equivalents to the concentrations of $\mathrm{B}(\mathrm{a}) \mathrm{P}$ alone, which can indicate the variation of risk for different environments. The annual number of lung cancer cases attributable to carcinogenic PAH compounds in 2005 was 58 persons per million. The $\mathrm{B}(\mathrm{a}) \mathrm{P}$ is the highest carcinogenic contributor, followed by $\mathrm{D}(\mathrm{ah}) \mathrm{A}$ and $\mathrm{B}(\mathrm{b}) \mathrm{F}$ (Pufulete et al. 2004). However, D(ah)A was suggested as a new surrogate compound to measure the toxicity of particle phase-PAHs because its toxicity is almost equal to that of $\mathrm{B}(\mathrm{a}) \mathrm{P}$. While estimating the toxicity of PAHs in road dust of Ulsan, Korea, Dong and Lee (2009) found a significant correlation coefficient between TEQ and total PAH concentrations (Dong and Lee 2009). From table 3 and figure 6 it was clear that toxic equivalence factor of B(a)P and Dib(ah)A have been found in higher side as compared to the other PAHs. Thus B(a)P and Dib(ah)A are the two most toxic and carcinogenic PAHs.

\section{Conclusions}

This is the first comprehensive information on PAH spatial distribution pattern at different distances $(1,2$ and $3 \mathrm{~m})$ from roadside soil in a fast developing city of India. This monograph studies the roadside soil contamination with PAHs and found 
Table 3. Toxic equivalent factor of different PAHs.

\begin{tabular}{lccc}
\hline PAHs & $\begin{array}{c}\text { Toxic equivalence } \\
\text { factor (TEF) }\end{array}$ & Liao et al. (2006) & Factor \\
\hline Nap & 0.001 & 0.77 & 0.00077 \\
Acenaphthene & 0.001 & 0.385 & 0.000385 \\
Acenaphthylene & 0.001 & 1.855 & 0.001855 \\
Fluorene & 0.001 & 1.405 & 0.001405 \\
Phenanthrene & 0.001 & 0.955 & 0.000955 \\
Anthracene & 0.001 & 1.805 & 0.001805 \\
Fluoranthene & 0.001 & 2.58 & 0.00258 \\
Pyrene & 0.001 & 1.805 & 0.001805 \\
Benz(a)anthracene & 0.1 & 4.275 & 0.4275 \\
Chrysene & 0.01 & 4.63 & 0.0463 \\
Benzo(b)fluoranthene & 0.1 & 4.735 & 0.4735 \\
Benzo(k)fluoranthene & 0.1 & 4.39 & 0.439 \\
Benzo(a)pyrene & 1 & 5.255 & 5.255 \\
Ideno(1,2,3-cd)P & 0.1 & 6.41 & 0.641 \\
Dibenz(a,h)anthracene & 1 & 7.765 & 7.765 \\
Benzo(g,h,i)perylene & 0.01 & 13.295 & 0.13295 \\
\hline
\end{tabular}

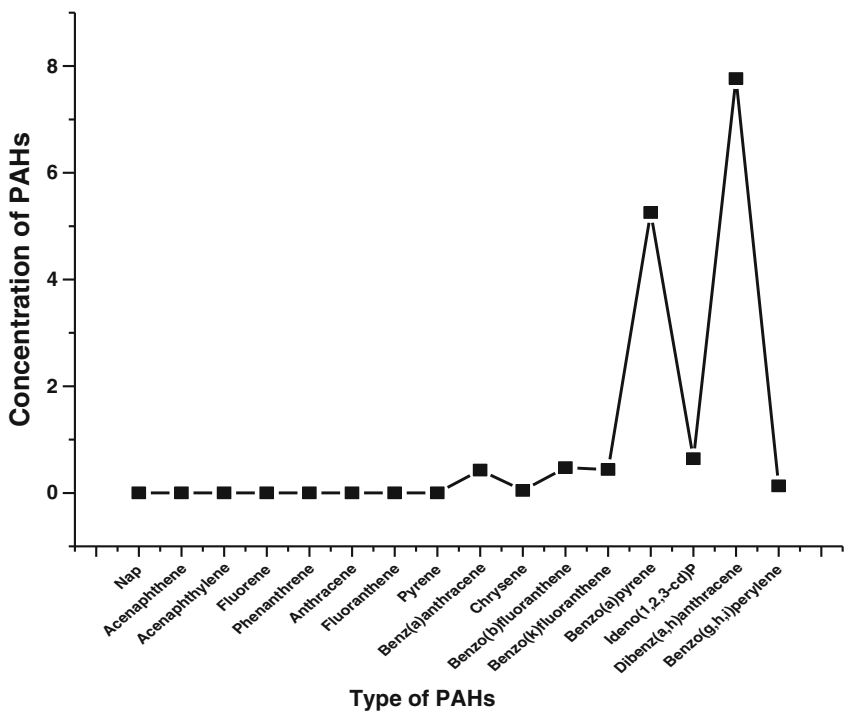

Figure 6. Concentration of $\mathrm{PAHs}$ with respect to toxic equivalent factor.

that $1 \mathrm{~m}$ distance from roadside is highly contaminated with many carcinogenic PAHs. Dib(ah)A and $\mathrm{B}(\mathrm{a}) \mathrm{P}$ were the two PAHs found in highest concentration at most intercepts round the year. Some of the PAHs were found to settle down at closer distance from the roadside as indicated by their absence at longer distance in soil. In general, average concentration of $16 \mathrm{PAHs}$ was found to be reduced with distance from 1 to $3 \mathrm{~m}$ in most of the cases at high traffic density intercepts, whereas average concentration of $16 \mathrm{PAHs}$ does not show any set pattern at average traffic density intercepts during three seasons. Higher concentration of high carcinogenic PAHs within city could be toxic to human. Toxic equivalency factor of $\mathrm{B}(\mathrm{a}) \mathrm{P}$ and Dib(ah)A was maximum as compared to other PAHs. It was also concluded from this study that developing cities were showing equal or even higher concentration of carcinogenic PAHs as compared to the metropolitan cities, which is a dangerous sign towards human exposure. This study suggests that the pollution of PAHs in developing cities like Jalandhar (India) should emphasize on controlling the traffic exhaust specially diesel exhaust.

\section{Acknowledgements}

One of the author Vaneet Kumar is grateful to MHRD New Delhi and authorities of National Institute of Technology, Jalandhar for providing Institute fellowship and laboratory facilities to carry out the present research work.

\section{References}

Banerjee D 2008 Study of precipitation chemistry over an industrial city; Int. J. Environ. Sci. Tech. 5(3) 331-338.

Cornelissen G, Rigterink H, Ferdinandy M M A and Van Noort P C M 1998 Rapidly desorbing fractions of PAHs in contaminated sediments as a predictor of the extent of bioremediation; Environ. Sci. Technol. 32 966-970.

Dong T T T and Lee B K 2009 Characteristics, toxicity, and source apportionment of polycyclic aromatic hydrocarbons (PAHs) in road dust of Ulsan, Korea; Chemosphere 74 1245-1253.

Edwards N T 1989 PAHs in the terrestrial environment-A review; J. Environ. Qual. 12 427-441. 
Fadzil Muhammad Fais, Mohd Tahir Norhayati, Khairul Mohad Wan and Wan Mohd Zin 2008 Concentration and distribution of PAHs in the town of Kota Bharu, Kelantan Darul Naim; The Malaysian J. Anal. Sci. 12(3) 609-618.

Guerin T F 1998 The extraction of aged polycyclic aromatic hydrocarbon (PAH) residues from a clay soil using sonication and a Soxhlet procedure: A comparative study; J. Environ. Monit. 1(1) 63-67.

Hunter J V, Sabatino T, Gomperts T and Mackenzie M J 1979 Contribution of urban runoff to hydrocarbon pollution; J. Water Pollut. Cont. Fed. 51(8) 2129-2138.

Jones K C, Stratford J A, Waterhouse K S and Vogt N B 1989 Organic contaminants in Welsh soils; Environ. Sci. Technol. 23 540-550.

Krauss M, Wilcke W and Wolfgang Z 2000 Availability of polycyclic aromatic hydrocarbons (PAHs) and polychlorinated biphenyls (PCBs) to earthworms in urban soils; Environ. Sci. Technol. 34(20) 4335-4340.

Kumar V and Kothiyal N C 2011a Distribution pattern and contamination level of some polycyclic aromatic hydrocarbons along roadside soil at major traffic intercepts during autumn in Jalandhar, India; Asian J. Chem. 23(3) 1363-1368.

Kumar V and Kothiyal N C 2011b Distribution behavior of polycyclic aromatic hydrocarbons in roadside soil at traffic intercepts within developing cities; Int. J. Environ. Sci. Tech. 8(1) 63-72.

Kumar V and Kothiyal N C 2012 Distribution behavior and carcinogenic level of some polycyclic aromatic hydrocarbons in roadside soil at major traffic intercepts within a developing city of India; Environ. Monit. Assess. 184 6239-6252.

Kumata H, Sanada Y, Takada H and Ueno T 2000 Historical trends of $n$-cyclohexyl-2 benzothiazolamine, 2(4-morpholinyl) benzothiazole, and other anthropogenic contaminants in the urban reservoir sediment core; Environ. Sci. Technol. 34(2) 246-253.

Lee C W, Lemieux P M, Gullet B K, Ryan J V and Kilgroe J D 1998 Research on emissions and mitigation of POPs from combustion sources; Stud. Environ. Sci. 72 361-378.

Li J, Zhang G, Li X D, Qi S H, Liu G Q and Peng X Z 2006 Source seasonality of polycyclic aromatic hydrocarbons (PAHs) in a subtropical city, Guangzhou, South China; Sci. Total Environ. 355(1-3) 145-155.

Liao B Y, Scott N M and Zhang J 2006 Impacts of gene essentiality, expression pattern, and gene compactness on the evolutionary rate of mammalian proteins; Mol. Biol. Evol. 23 2072-2080.
Lunch A 2005 The carcinogenic effect of polycyclic aromatic hydrocarbons (London: Imperial College Press), ISBN 1-86094-417-5.

Masih Amit and Ajay Taneja 2006 Polycyclic aromatic hydrocarbons (PAHs) concentrations and related carcinogenic potencies in soil at a semi-arid region of India; Chemosphere 65(3) 449-456.

Mastral A M, Callen M S and Murillo R 1996 Assessment of $\mathrm{PAH}$ emissions as a function of coal combustion variables; Fuel 75(13) 1533-1536.

Nam J J, Song B H, Eom K C, Lee S H and Smith A 2003 Distribution of PAHs in agricultural soils in South Korea; Chemosphere 50 1281-1289.

Neilson A H 1998 The Handbook of Environmental Chemistry $3 \mathrm{~J}$ : PAHs and Related Compounds Biology (Berlin: Springer-Verlag), pp. 312-350.

Petry T, Schmid P and Schlater C 1996 The use of toxic equivalency factors in assessing occupational and environmental health risk associated with exposure to airborne mixtures of polycyclic aromatic hydrocarbons (PAHs); Chemosphere 32 639-648.

Pufulete M, Battershill J, Boobis A and Fielder R 2004 Approaches to carcinogenic risk assessment for polycyclic aromatic hydrocarbons: A UK perspective; Regulatory Toxicology and Pharmacology 40 54-66.

Ray Sharmila, Khillare P S, Tripti Agarwal and Vijay Shridhar 2008 Assessment of PAHs in soil around the International Airport in Delhi, India; J. Hazardous Materials 156(1-3) 9-16.

Rogge W F, Hildemann L M, Mazurek M A, Cass G R and Simoneit B R T 1993 Sources of fine organic aerosol 3. Road dust, tire debris, and organometallic brake lining dust: Roads as sources and sinks; Environ. Sci. Technol. 27(9) 1892-1904.

Skrbic B, Cvejanov J Mladenovic and Natasa Durisic 2005 Polycyclic aromatic hydrocarbons in surface soils of Novi Sad and bank sediment of the Danube River; J. Environ. Sci. Health A 40 29-42.

Takada H, Onda T and Ogura T 1990 Determination of polycyclic aromatic hydrocarbons in urban street dusts and their source materials by gas chromatography; Environ. Sci. Technol. 24 1179-1186.

Williams P T 1990 Sampling and analysis of polycyclic aromatic compounds from combustion systems - a review; J. Inst. Energy $6322-30$.

Yang S Y N, Connell D W, Hawker D W and Kayal S I 1991 PAHs in air, soil and vegetation in the vicinity of an urban roadway; Sci. Total Environ. 102 229-240. 